\title{
STUDI FLEKSIBILITAS PADA WADAH KOMUNITAS TANGGAP BENCANA BANJIR DI JAKARTA TIMUR
}

\author{
Revina Howin (iafudi $^{1)}$, Diah Anggraini) ${ }^{21}$ \\ 1)Program Studi S1 Arsitektur, Fakultas Teknik, Universitas Tarumanagara, revinahowin18@gmail.com \\ 2) Program Studi S1 Arsitektur, Fakultas Teknik, Universitas Tarumanagara, diaha@ft.untar.ac.id
}

Masuk: 04-07-2021, revisi: 14-08-2021, diterima untuk diterbitkan: 23-10-2021

\begin{abstract}
Abstrak
Bencana banjir adalah sebuah fenomena alam yaitu luapan air yang menenggelamkan daratan dikarenakan volume air yang meningkat. Dikarenakan bencana banjir ini, warga diharuskan untuk mengungsi ke tempat pengungsian atau mengungsi ke lantai 2 rumah mereka. Selain menghambat aktivitas dan tempat berhuni, warga juga kekurangan air bersih dan mengalami kerugian yang cukup parah. Selain itu tempat pengungsian yang disediakan oleh pemerintah juga kurang layak. Proyek Resilience Komunitas Permukiman Kumuh Terdampak Banjir ini merupakan proyek yang memiliki tujuan untuk membangun sebuah komunitas yang terdiri atas masyarakat permukiman kumuh agar dapat bertahan ketika bencana banjir terjadi. Dibangunnya sebuah fasilitas untuk komunitas di Jakarta Timur tepatnya di kawasan rawan banjir ini berguna sebagai tempat pengungsian ketika bencana dan juga dapat digunakan oleh warga untuk beraktivitas sehari-hari ketika situasi bencana. Dalam perancangannya digunakan metode fleksibilitas dan adaptibilitas mengingat fungsi bangunan yang akan difungsikan dalam 2 kondisi yaitu situasi ketika bencana dan situasi ketika normal. Hal ini menyebabkan adanya perubahan penggunaan sebuah ruang berdasarkan situasi yang dihadapi pengguna dimana sebuah ruang dapat digunakan sebagai tempat berkegiatan sehari-hari dan sebagai tempat pengungsian. Diharapkan fasilitas ini dapat digunakan semaksimal mungkin dalam berbagai keadaan.
\end{abstract}

Kata kunci: Banjir; Bencana; Komunitas; Permukiman Kumuh; Resilience

\begin{abstract}
Flood disaster is a natural phenomenon, namely the overflow of water that drowns the land due to the increased volume of water. Due to this flood disaster, residents were required to evacuate to a refugee camp or evacuate to the 2nd floor of their house. In addition to hampering activities and places to live, residents also lack clean water and suffer severe losses. In addition, the refugee camps provided by the government are also inadequate. The Resilience Project of Slums Affected by Flood Communities is a project that aims to build a community consisting of slum communities so that they can survive when a flood disaster occurs. The construction of a facility for the community in East Jakarta, precisely in a floodprone area, is useful as a refuge during a disaster and can also be used by residents for daily activities during a disaster situation. In the design, flexibility and adaptability methods are used considering the function of the building to be functioned in 2 conditions, namely the situation during a disaster and the situation when it is normal. This causes a change in the use of a space based on the situation faced by the user where a space can be used as a place for daily activities and as a place of refuge. It is hoped that this facility can be used as much as possible in various circumstances.
\end{abstract}

\section{Keywords: Community; Disaster; Flood; Resilience; Slum Communities}

\section{PENDAHULUAN}

\section{Latar Belakang}

Banjir merupakan suatu bencana yang diakibatkan oleh curah hujan yang tinggi dan saluran pembuangan air yang kurang baik sehingga merendam beberapa wilayah daratan. Banjir juga 
dapat terjadi akibat rusaknya sistem saluran air sehingga beberapa daerah rendah terkena dampak kiriman banjir.

Pertumbuhan permukiman di bantaran sungai meningkat sangat pesat diakibatkan oleh kebutuhan penduduk akan lahan dan tempat tinggal semakin meningkat. Pemerintah sudah meminta warga untuk pindah namun hanya sebagian warga yang menurut untuk pindah dan sebagian lagi menolak atau tidak menyanggupi untuk pindah dikarenakan harga sewa yang tinggi dan bila mereka menetap di rusun, mereka khawatir kehilangan mata pencaharian seperti berdagang. Kebanyakan warga yang tinggal di bantaran sungai ini juga menggunakan air sungai untuk kebutuhan sehari-hari mereka dan ini tidak memenuhi standar syarat kesehatan.

Ketika bencana banjir terjadi, warga sudah sigap membungkus dan mengamankan barang mereka. Selain itu, warga lain juga sigap untuk memberikan pengumuman yang disebarkan melalui pengeras suara di musholla mengenai tanda-tanda alam yang menunjukkan akan datangnya bencana banjir. Pada saat tanggap darurat bencana, fasilitas sosial seperti masjid, gelanggang olahraga, dan RPTRA sering kali ditunjuk sebagai tempat penampungan sementara. Tujuan pengungsian darurat adalah untuk menyelamatkan dan mengamankan para warga terdampak bencana dan menjauhkan mereka dari tempat yang dianggap berbahaya ke tempat yang aman agar pemberian bantuan dan pertolongan menjadi mudah. Selain itu lokasi pengungsian juga harus dapat memenuhi kebutuhan hidup pengungsi yaitu manusia baik sebagai individu maupun sebagai kelompok masyarakat.

Pada umumnya, banjir terjadi tidak menentu menyesuaikan dengan cuaca di musim penghujan dan juga dapat diprediksi dari informasi atas datangnya air kiriman. Pemerintah sudah mengusahakan sistem pengendalian banjir agar surut dalam waktu 6 jam, namun biasanya waktu yang dibutuhkan bagi warga untuk mengungsi hingga kembali kerumahnya serta membersihkan tempat tinggalnya membutuhkan 5-7 hari.

\section{Rumusan Permasalahan}

Berbagai masalah selalu dialami masyarakat yang tinggal di daerah rawan banjir. Fasilitas pengungsian sangat diperlukan untuk menampung korban banjir yang sifatnya sementara. Maka permasalahan yang akan diangkat dalam studi ini adalah:

a. Bagaimana merancang suatu wadah bagi warga terkena bencana banjir yang dapat memitigasi dampak banjir pada para pengungsi.

b. Bagaimana menghasilkan program bangunan yang fleksibel baik untuk menunjang aktivitas pengungsi saat bencana banjir namun tetap dapat dimanfaatkan saat situasi normal.

\section{Tujuan}

Tujuan penelitian ini adalah untuk menciptakan arsitektur yang dapat memenuhi kebutuhan masyarakat baik ketika situasi banjir di musim penghujan maupun musim kemarau yaitu sebagai tempat pengungsian maupun sebagai tempat warga beraktivitas normal serta meningkatkan kesadaran masyarakat agar menjalani pola hidup yang sehat dan meningkatkan edukasi dan keterampilan masyarakat sekitar. Selain itu diharapkan juga arsitektur ini dapat membantu mengurangi dampak dari banjir yang terjadi di kawasan permukiman padat penduduk.

\section{KAJIAN LITERATUR}

Kata ekologi merupakan istilah yang menjelaskan hubungan hewan dengan lingkungan organik maupun anorganiknya. Kata ekologi sendiri berasal dari bahasa Yunani yaitu oikos, yang memiliki arti rumah tangga, rumah, atau tempat tinggal. Oleh karena itu ekologi berkaitan dengan organisme dan lingkungannya (Ernst Haeckel, 1866). Ecoshophy merupakan hubungan sosial ekologi yang mencakup hubungan sosial, pandagan manusia, dan juga hubungan alam (Guattari, 1989).

Ecological Design adalah prinsip desain yang terintegrasi untuk bertanggung jawab secara ekologis. Hal inilah yang menghubungkan aristektur hijau, teknik ekologi, dan bidang lainnya. 
Desain ekologis adalah sebuah ide yang menempatkan ekologi sebagai latar belakang desain yang mencakupbeberapa hal seperti melestarikan habitat, meminimalisir penggunaan energi dana material, mengurangi polusi, serta mendorong komunitas kesehatan dan keindahan (Van der Ryn, 1996).

Parameter dalam arsitektur menuju beyond ecology mencakup (Agustinus Sutanto, 2021):

a. Energy \& Mission, menerapkan zero $\mathrm{CO} 2$ emission dan mengurangi efek karbon dalam materialkonstruksi

b. Adaption, meriset desain yang berkaitan dengan berbagai dampak seperti kekeringan, banjir,perubahan populasi, dsb

c. Resilience, membangun ketahanan hunian dan pemulihan cepat setelah terjadinya bencanaalam

d. Sustainable Digital, melihat data lingkungan dalam melakukan taktik dan strategi untuk membangun sesuatu yang berkelanjutan

e. New Technology, memanfaatkan terknologi baru untuk meningkatkan kualitas terapan ruangdalam program bangunan

f. Context, Melihat posisi dalam hubungan lingkungan dimana posisi keruangan akan ditempatkan.

Beyond ecology bukan hanyalah tentang eksplorasi diluar bumi dan membuat ekologi baru di luar bumi, melainkan mengeksplorasi atau menghasilkan ciptaan baru tentang ekologi yang dibuat oleh manusia yang akan menjadi plug-in bagi ekosistem di bumi ini. Penelusuran dan eksplorasi dari berbagai ekologi dapat membuat penciptaan ekologi baru dan juga pengembangan ekologi yang sudah ada yang diharapkan mampu mendukung ekologi yang sudah ada dan sedang berlangsung (Eco-logic,Suwardana Winata, 2021).

Metode desain dengan strategi fleksibilitas untuk menjawab kebutuhan pengguna bersadarkan waktu dan cara yang efektif terdiri dari 7 metode (Designing Flexibility and Adaptibility, 2019).

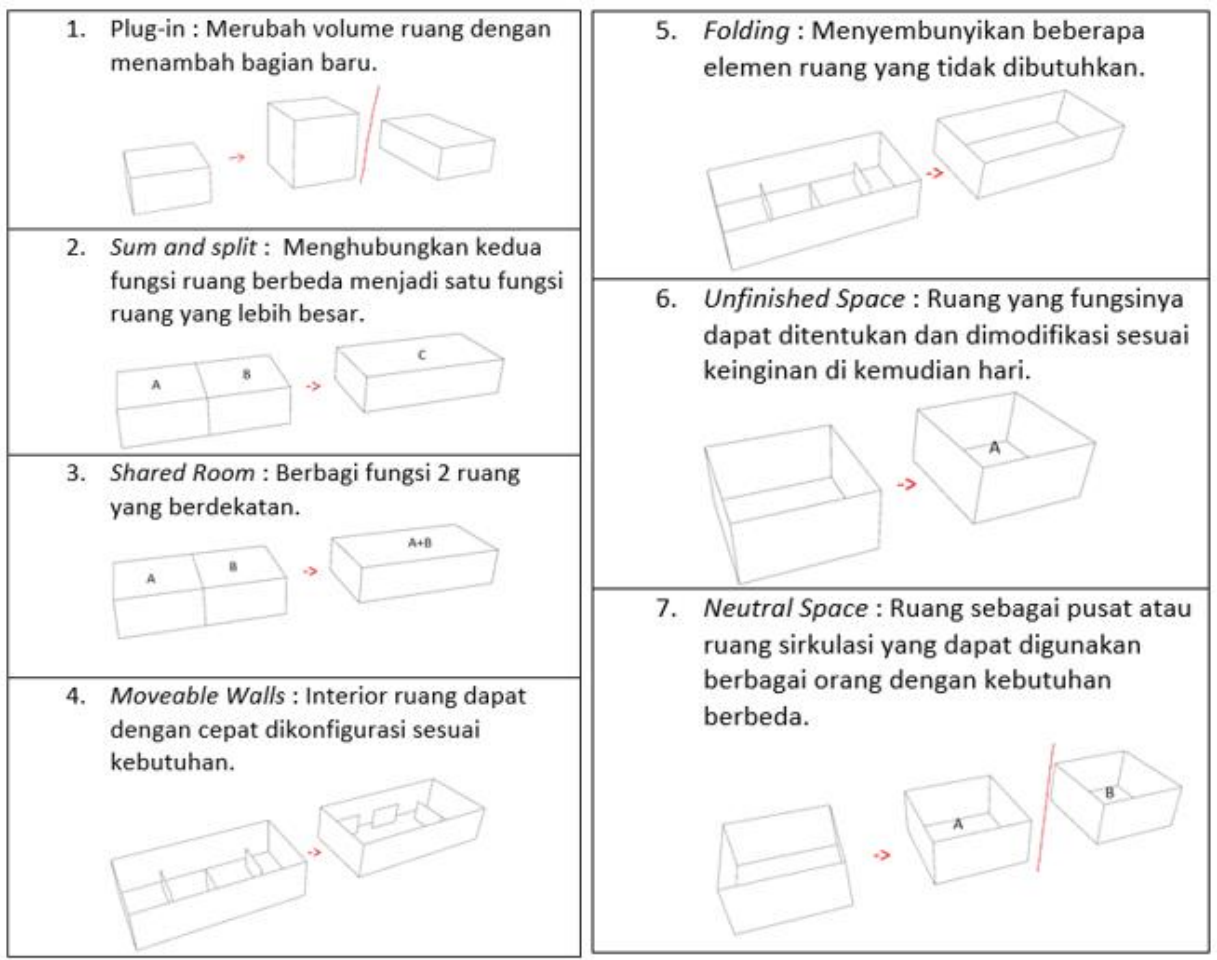

Gambar 1. Metode Desain Fleksibilitas dan Adaptibilitas 


\section{METODE Metode Desain}

Sumber: Scuderi, 2019

Penelitian ini menggunakan metode deskriptif kualitatif dalam proses pengumpulan, interpretasi dan analisis data. Pemahaman mengenai permasalahan yang diangkat diperolah melalui studi literatur tentang berbagai teori yang mendukung, mengumpulkan berbagai informasi tentang isu yang diangkat melalui internet serta memahami materi yang didapatkan dalam kuliah Studio Perancangan Arsitektur 8.31. Investigasi kawasan dilakukan menggunakan googlemaps.com serta earth.google.com. Selain itu, data penunjang sosial, ekonomi, dan budaya di sekitar kawasan dikaji dari media massa, jurnal, statistik pemerintah, dan lain sebagainya.

Dalam proses penyusunan konsep perancangan, studi ini mengacu pada metode fleksibilitas dan adaptibilitas yang dinilai sesuai dengan kebutuhan suatu bangunan yang dapat melayani dua peristiwa yang berbeda yaitu sebagai pengungsian ketika terjadi banjir dan melayani kegiatan masyarakat saat kondisi normal.

\section{Konsep \& Gubahan Massa}

Dalam pengolahan gubahan massa bangunan, selain berdasarkan analisis tapak, juga mengambil ombak sebagai tema perancangan, yang menggambarkan suasana banjir, dan air yang mengalir.

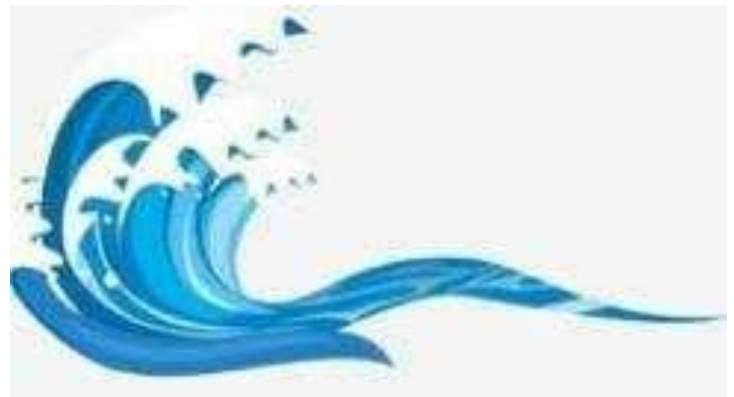

Gambar 2. Ombak

Sumber: id.pinterest.com, 2021

Bentuk gubahan massa diambil dari ide ombak yang bergerak dari ketinggian rendah hingga semakin tinggi. Selain itu bentuk gubahan massa juga diambil dari ide cipratan air. Tema ombak juga diterapkan pada proyek yang dicerminkan pada aktivitas yang terjadi di dalam bangunan yang menerus dan tidak berhenti. Artinya adalah walaupun situasi sedang dalam evakuasi ataupun situasi bencana, aktivitas di dalam bangunan tetap dapat berjalan terus. Walaupun warga mengungsi, mereka tetap dapat melakukan kegiatan sehari-hari mereka di dalam bangunan. Hal ini membuat bangunan berfungsi semaksimal mungkin baik dalam situasi normal maupun dalam situasi bencana.

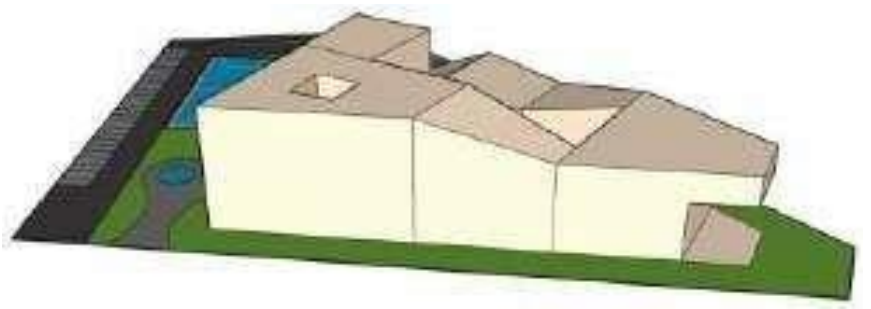

Gambar 3. Perspektif Gubahan Massa

Sumber: Dokumen Pribadi, 2021

\section{DISKUSI DAN HASIL}

\section{Investigasi Lokasi Penelitian}

Bencana banjir pada awal tahun 2020 di Jakarta yang terparah tercatat berada di sekitar 
kawasan Sungai Ciliwung, Jakarta Timur. Banjir pada lokasi tersebut mencapai kedalaman lebih dari150 cm hingga 3 meter.

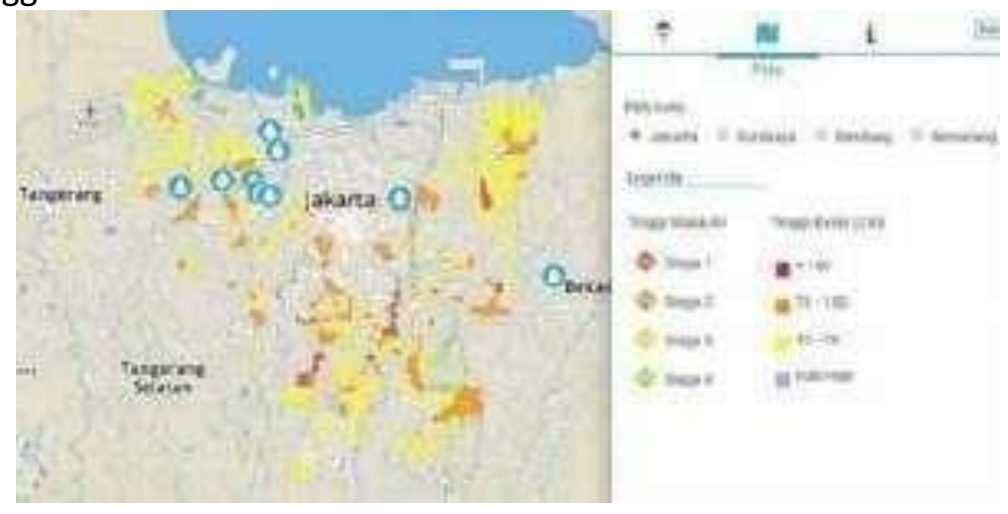

Gambar 4. Peta Daerah Terdampak Banjir Februari 2020 Sumber : petabencana.id, 2020

Berdasarkan data pada tahun 2021, titik terjadinya banjir terparah berada di Jl. Letjen MT Haryono yang berada di sekitar Kali Cipinang serta di kelurahan Bidara Cina yang berada di sampingSungai Ciliwung.

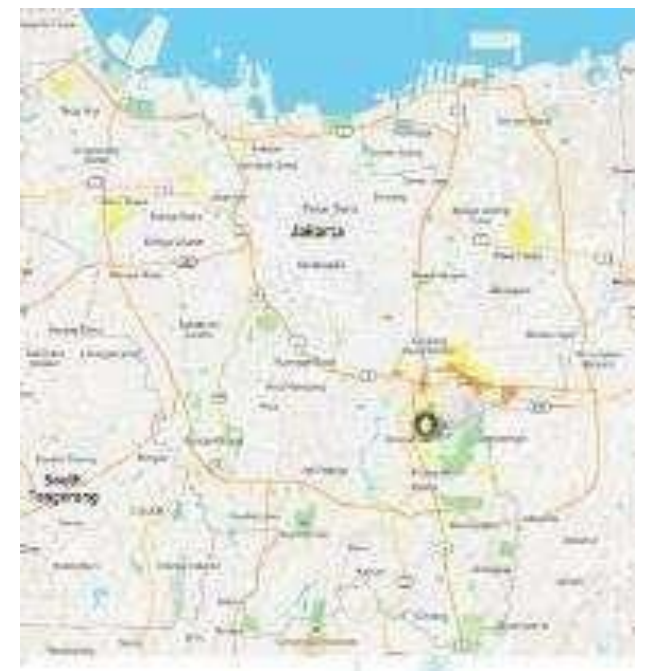

Gambar 5. Peta Sebaran Banjir 19 Februari 2021

Sumber: Petabencana.id, 2021

\section{Analisis Tapak}

Lokasi tapak berada di jalan lokal yang sangat dekat dengan permukiman warga dan juga dekat dengan kawasan rawan banjir. Ketika situasi bencana banjir terparah, tapak dapat terkena dampak banjir dari 10 hingga $30 \mathrm{~cm}$. 


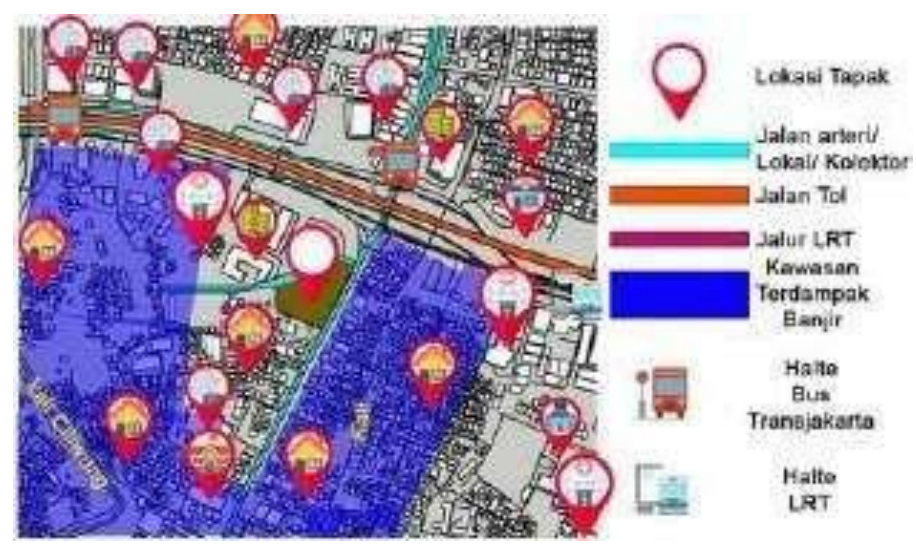

Gambar 6. Fasilitas Sekitar Tapak

Sumber: Dokumen Pribadi, 2021

Tapak berada di Jl Dewi Sartika, Jakarta Timur dengan luas $9.254 \mathrm{~m}^{2}$ dan berada pada zona peruntukan fungsi perdagangan, perkantoran, dan jasa berdasarkan Peta Tata Guna Lahan Kelurahan Bidara Cina. Sesuai TPZ, peraturan di tapak tersebut adalah sebagai berikut:

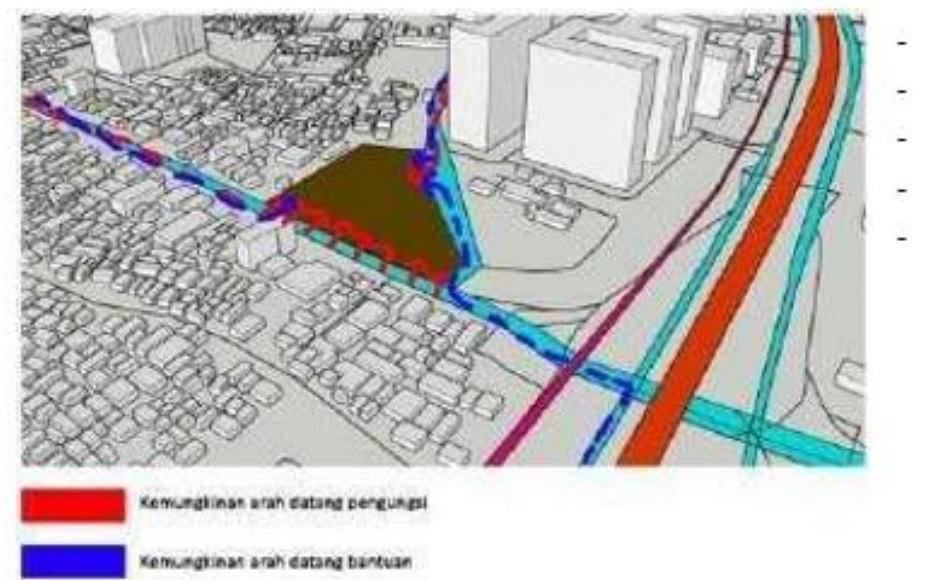

KDB: 50

KLB: 2

KB: 4

$\mathrm{KDH}: 35$

KTB: 50

Gambar 7. Kemungkinan Arah Datang Pengungsi Ketika Bencana Sumber: Dokumen Pribadi, 2021

Ketika bencana banjir terjadi, pengungsi kebanyakan berasal dari kawasan sekitar Sungai Ciliwung serta dari permukiman di belakang tapak dan juga dari kawasan Jalan Letjen MT Haryono.

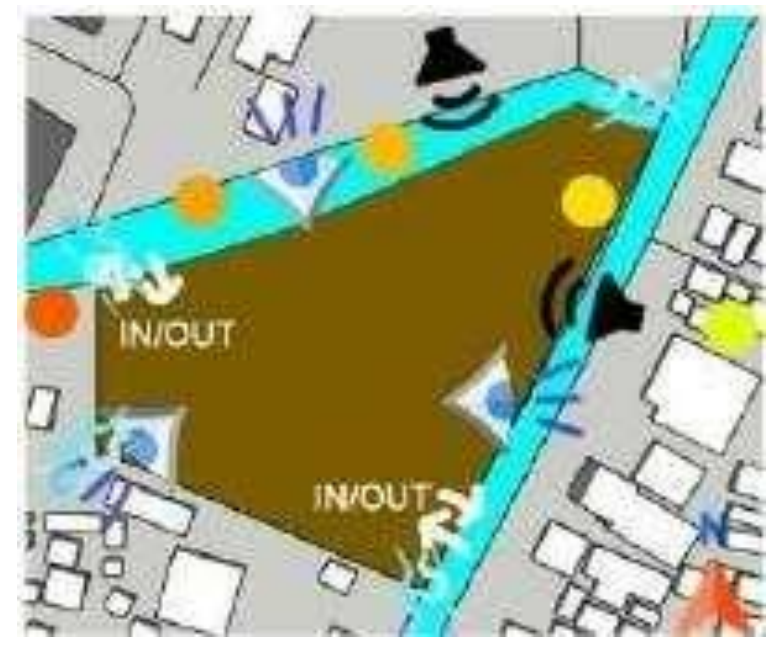

Gambar 8. Analisis Tapak 
Keberadaan bangunan tinggi di sisi barat menyebabkan cahaya matahari sore terbatas, dan view pada sisi ini kurang baik. Sementara itu aktivitas lingkungan sekitar tapak seperti ramainya pedagang kecil dan lalu lintas kendaraan bermotor yang padat, menyebabkan tingkat kebisingan yang tinggi pada tapak.

\section{Program Aktivitas \& Ruang}

Aktivitas yang terjadi pada bangunan direncanakan untuk melayani dua situasi yang berbeda, yaitu situasi normal dimana aktivitas pada bangunan berjalan semestinya sesuai fungsinya dan situasi bencana dimana beberapa fungsi ruang beralih fungsi untuk mencukupi kebutuhan para pengungsi bencana. Berikut adalah gambar perbandingan program aktivitas ruang pada bangunan ketika situasi normal dan bencana.

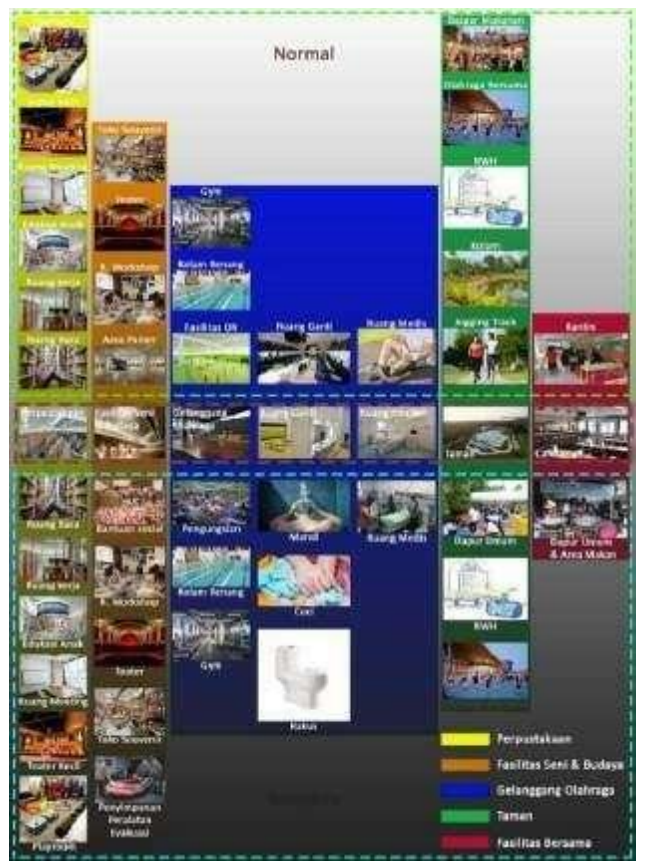

Gambar 9. Perbandingan Aktivitas Ruang Ketika Situasi Normal \& Bencana Sumber: Dokumen pribadi, 2021

\section{HASIL DAN PEMBAHASAN}

\section{Hasil Rancangan}

Hasil rancangan menghasilkan ruang-ruang yang sama namun dapat melayani kegiatan yang berbeda secara bergantian di dalam bangunan. Bangunan dapat berfungsi menampung kegiatan rutin komunitas ketika situasi normal dan berfungsi sebagai tempat pengungsian ketika situasi bencana. Metode desain yang digunakan merupakan metode desain fleksibilitas dan adaptibilitas. Salah satu contohnya adalah pada penggunaan ruang pamer yang diubah dengan cara moveable walls yaitu mengkonfigurasi ruang sesuai dengan kebutuhan. Area pamer yang awalnya digunakan untuk penyewaan pameran temporer dialihfungsikan menjadi tempat pengungsian ketika terjadinya bencana.

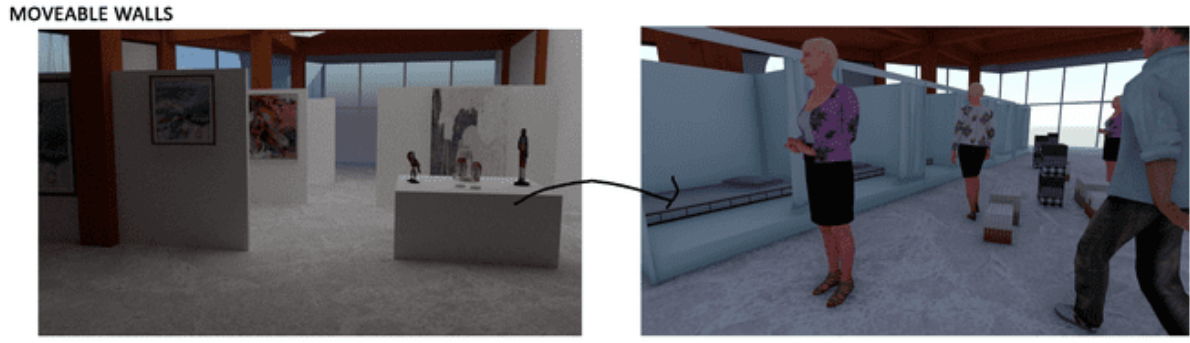


Gambar 10. Aplikasi Penggunaan Moveable Walls pada Desain Sumber: Dokumen Pribadi, 2021

Contoh penggunaan metode desain fleksibilitas dan adaptibilitas pada bangunan adalah pada ruang teater. Hal ini diaplikasikan dengan menyembunyikan beberapa elemen ruang yang tidak dibutuhkan seperti furnitur. Dalam hal ini ruang teater dialihfungsikan menjadi tempat pengungsian ketika terjadinya bencana dengan menggunakan metode folding yaitu furnitur kursi penonton disembunyikan dan fungsi ruang berubah menjadi tempat pengungsian.

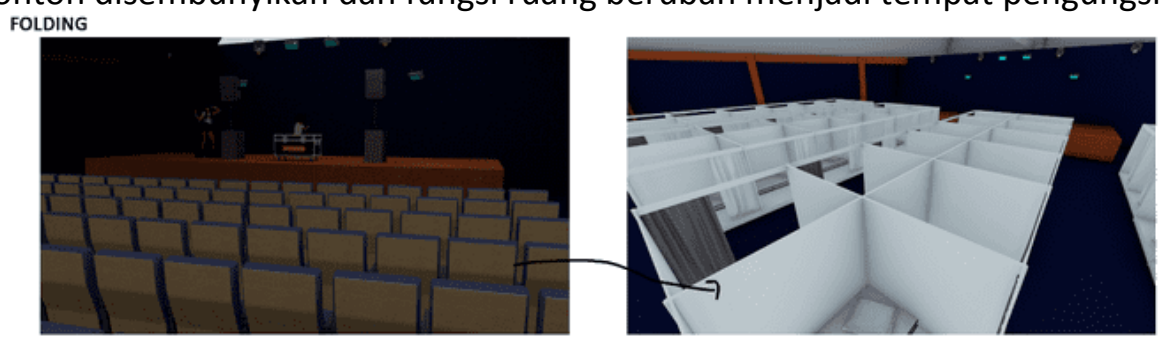

Gambar 11. Aplikasi Penggunaan Folding pada Desain Sumber: Dokumen Pribadi, 2021

Berikut adalah denah lantai dasar bangunan ketika situasi normal. Pengunjung dapat masuk lounge kemudian dapat menuju ke berbagai tempat seperti ruang kursus, ruang workshop, area pamer, serta lapangan basket dan area pejalan kaki yang juga digunakan sebagai jogging track.

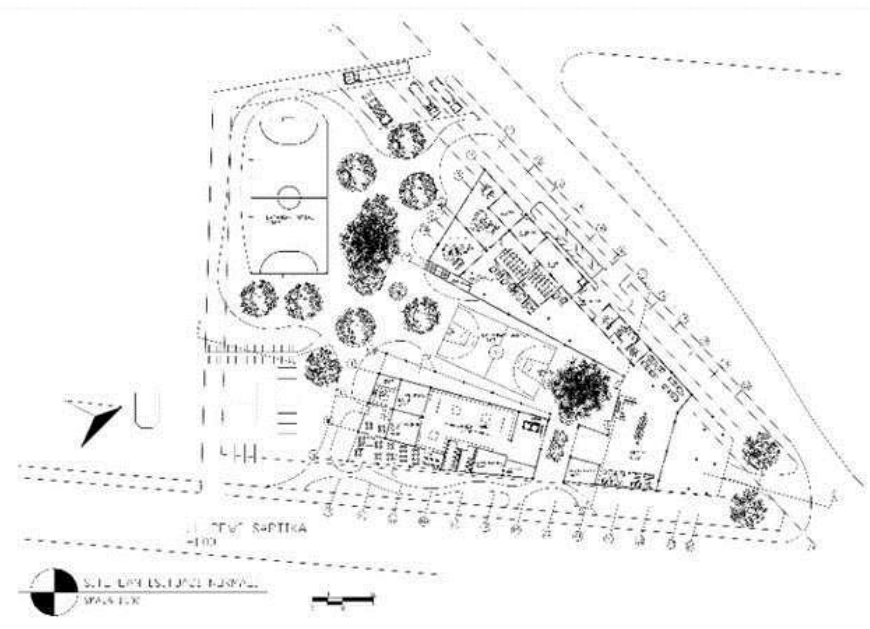

Gambar 12. Denah Lantai 1 Situasi Normal Sumber: Dokumen Pribadi, 2021

Pada situasi bencana beberapa fungsi ruang dapat diubah. Seperti pada lapangan futsal fungsi yang awalnya digunakan untuk olahraga dan bermain bola dijadikan tempat untuk dapur umum dan area makan warga. Lapangan basket serta area pamer juga beralih fungsi menjadi tempat pengungsian. Sedangkan lounge yang tadinya digunakan sebagai ruang tunggu digunakan sebagai area berkumpulnya warga yang baru datang untuk mengungsi. 


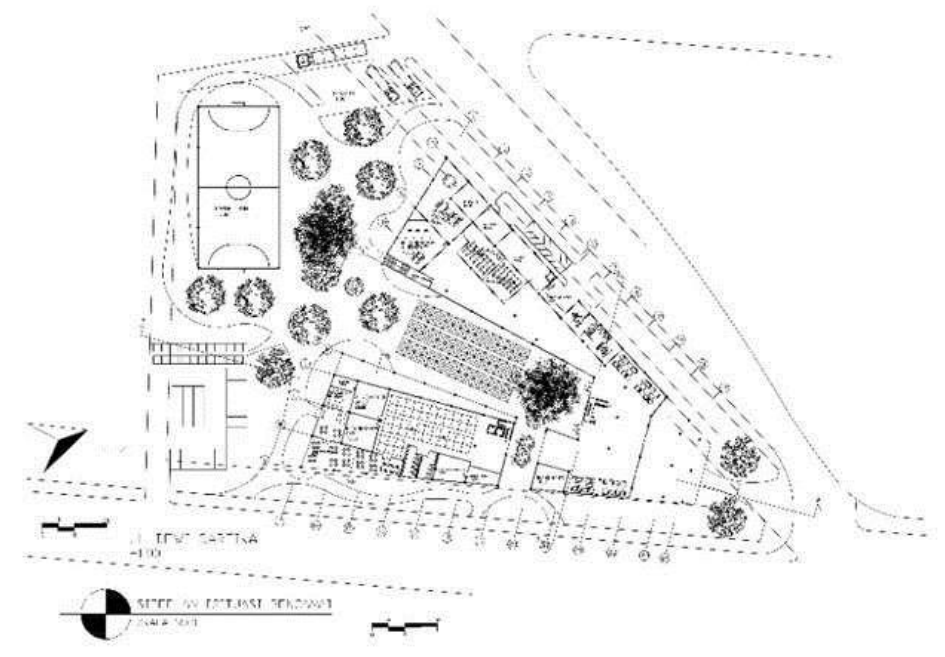

Gambar 13. Denah Lantai 1 Situasi Bencana

Sumber: Dokumen Pribadi, 2021

Pada lantai 2 bangunan, pengunjung dapat memanfaatkan fasilitas perpustakaan yang disediakan. Selain itu juga disediakan area pamer temporer yang dapat disewakan oleh orang dari luar yang ingin memamerkan karya seni mereka. Pada lantai 2 bangunan ini juga disediakan selasar teras di depan perpustakaan dan taman untuk menonton berbagai aktivitas outdoor seperti pertandingan basket yang berada di lantai 1 . Selain itu pada basement bangunan digunakan untuk utilitas dan penyimpanan peralatan untuk evakuasi warga ketika terjadinya bencana.

Pada situasi bencana, area pamer di lantai 2 juga dialihfungsikan menjadi tempat pengungsian warga. Dimana dibuatnya tempat pengungsian dari pvc yang diberi partisi setiap 2 meter sebagai pembatas tempat tidur untuk 1 keluarga. Sementara itu, perpustakaan dan taman pada lantai 2 berfungsi sebagaimana mestinya.

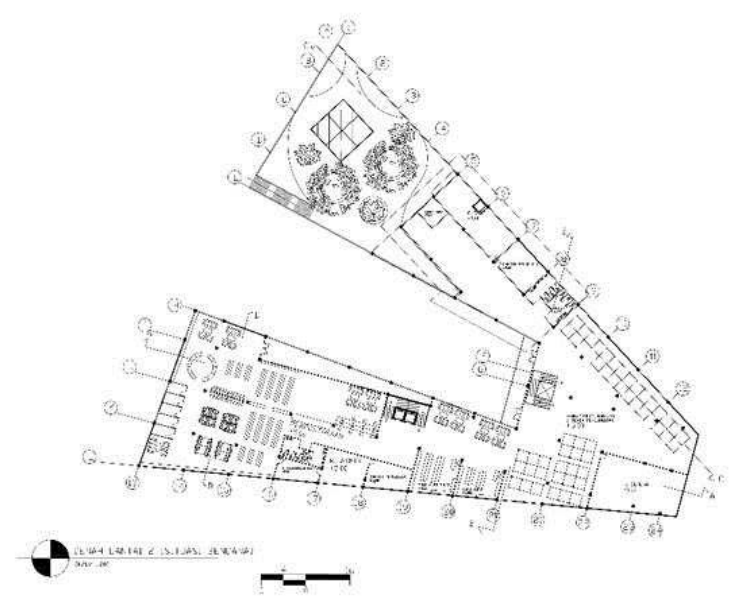

Gambar 14. Denah Lantai 2 Ketika Situasi Bencana Sumber: Dokumen Pribadi, 2021

Pada lantai 3 bangunan terdapat teater untuk penampilan seni, laboratorium bahasa dan komputer bagi warga dan workshop memasak. Taman juga terdapat di lantai 3 sebagai penghubung antara bangunan depan yang terdiri dari 3 lantai dan bangunan belakang yang terdiri dari 4 lantai. Taman ini juga dapat digunakan oleh warga untuk menonton pertandingan basket di lantai 1. 


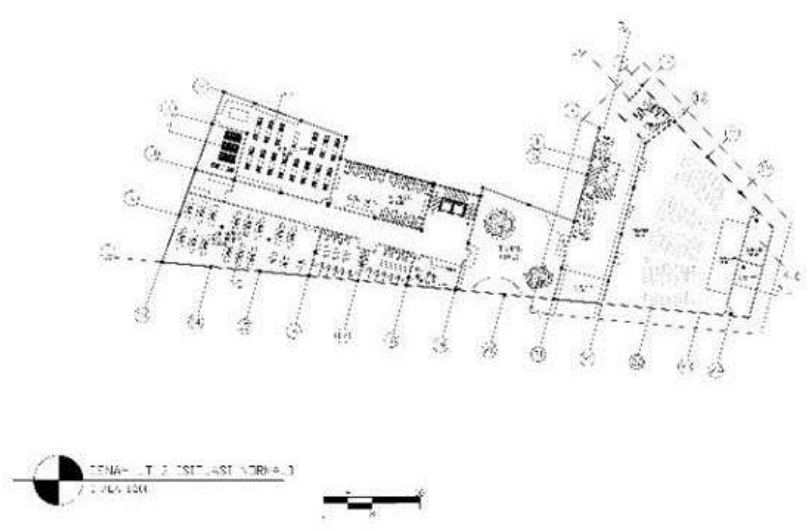

Gambar 15. Denah Lantai 3 Situasi Normal Sumber: Dokumen Pribadi, 2021

Pada situasi bencana, teater di lantai 3 ini dialihfungsikan menjadi tempat pengungsian dengan memindahkan kursi penonton dan digantikan dengan partisi 2 meter untuk tiap keluarga pengungsi. Sementara itu fungsi ruang kursus bahasa dan komputer juga berubah menjadi tempat penyewaan komputer bagi pengungsi yang ingin bekerja atau membutuhkan internet dan komputer dalam melakukan kegiatannya. Ruang workshop memasak juga berubah menjadi dapur umum dan ruang medis diperuntukkan bagi warga yang membutuhkan perawatan intensif.

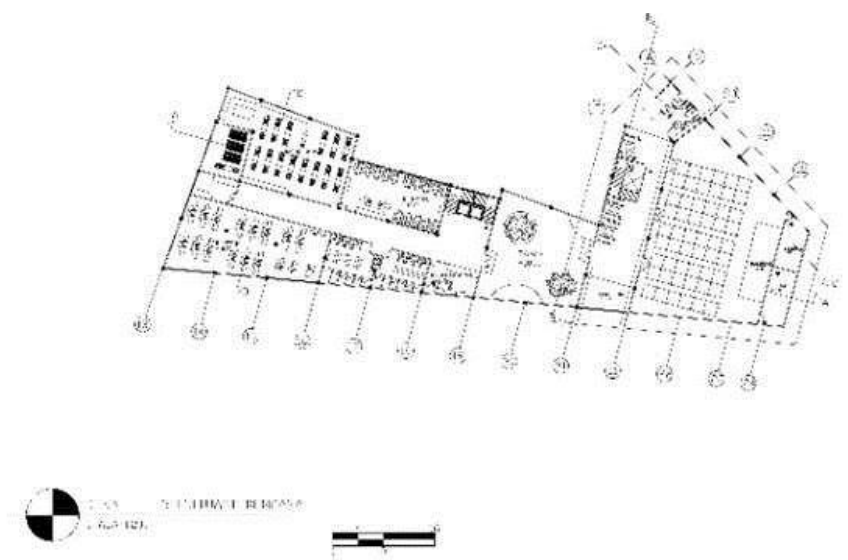

Gambar 16. Denah Lantai 3 Situasi Bencana

Sumber: Dokumen Pribadi, 2021

Pada lantai 4 bangunan dikhususkan untuk fasilitas olahraga dimana terdapat 2 buah lapangan badminton indoor serta area gym untuk berolahraga dan juga aula serbaguna yang dapat digunakan untuk berbagai komunitas seperti pencak silat, bela diri, karate, taekwondo, dan lainlainnya yang membutuhkan area yang cukup luas untuk melakukan aktivitasnya. 


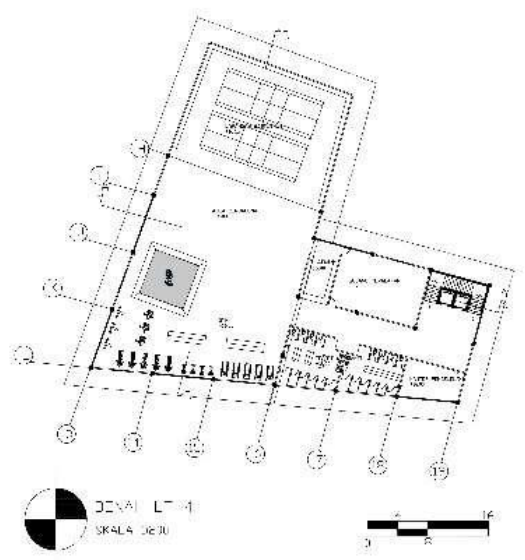

Gambar 17. Denah Lantai 4

Sumber: Dokumen Pribadi, 2021

Area pintu masuk menuju bangunan memiliki 2 akses dan keduanya diperuntukkan bagi pejalan kaki dimana pintu masuk yang utama berada di Jalan Dewi Sartika. Pengungjung dapat langsung menuju ke lounge, area pamer, atau lapangan basket melalui pintu masuk ini.

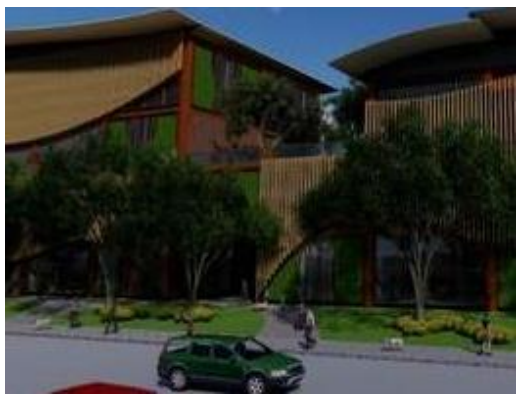

Gambar 18. Pintu Masuk Jalan Dewi Sartika

Sumber: Dokumen Pribadi, 2021

Desain bangunan sendiri menggunakan second skin louver yang bermaterial dari aluminium. Hal ini digunakan untuk mengurangi panasnya sinar matahari yang langsung menuju ke bangunan. Selain itu adanya vertical garden pada dinding bangunan juga untuk membuat kesan lebih sejuk dan memenuhi konsep beyond ecology.

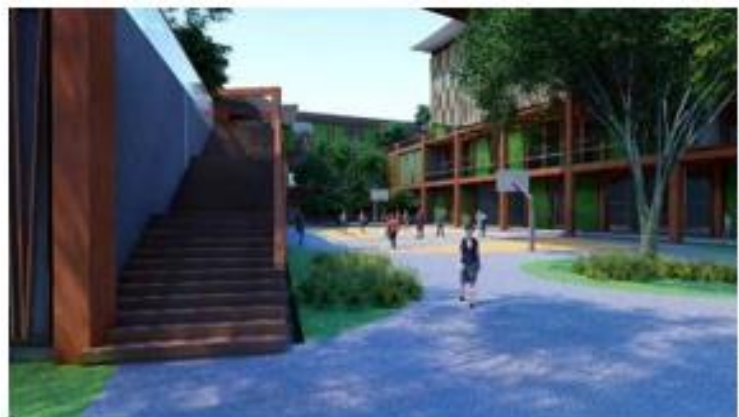

Gambar 19. Situasi di Dalam Tapak Sumber: Dokumen Pribadi, 2021

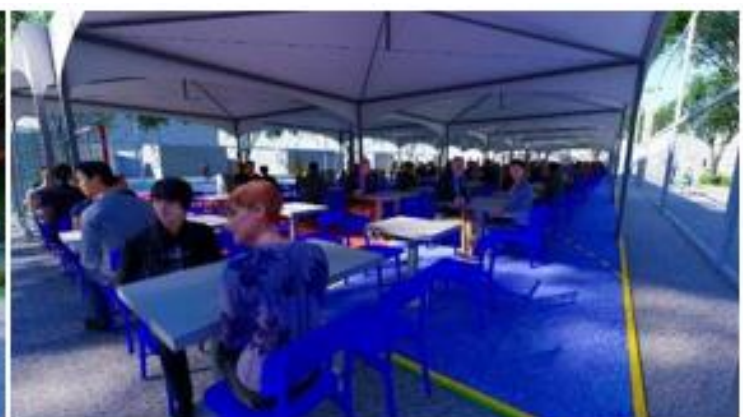

Gambar 20. Lapangan Futsal Ketika Situasi Bencana

Sumber: Dokumen Pribadi, 2021 


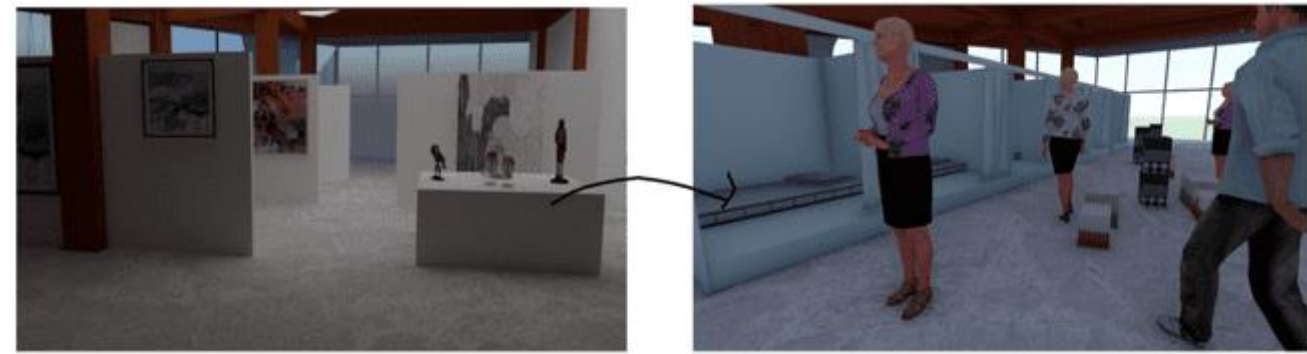

Gambar 21. Perbandingan Fungsi Area Pamer Ketika Situasi Normal \& Bencana Sumber: Dokumen Pribadi, 2021

Sementara itu pada potongan bangunan dapat terlihat penggunaan second skin louver sebagai bagian dari tampak bangunan dan juga untuk menghalau sinar matahari terik yang langsung masuk ke dalam bangunan.

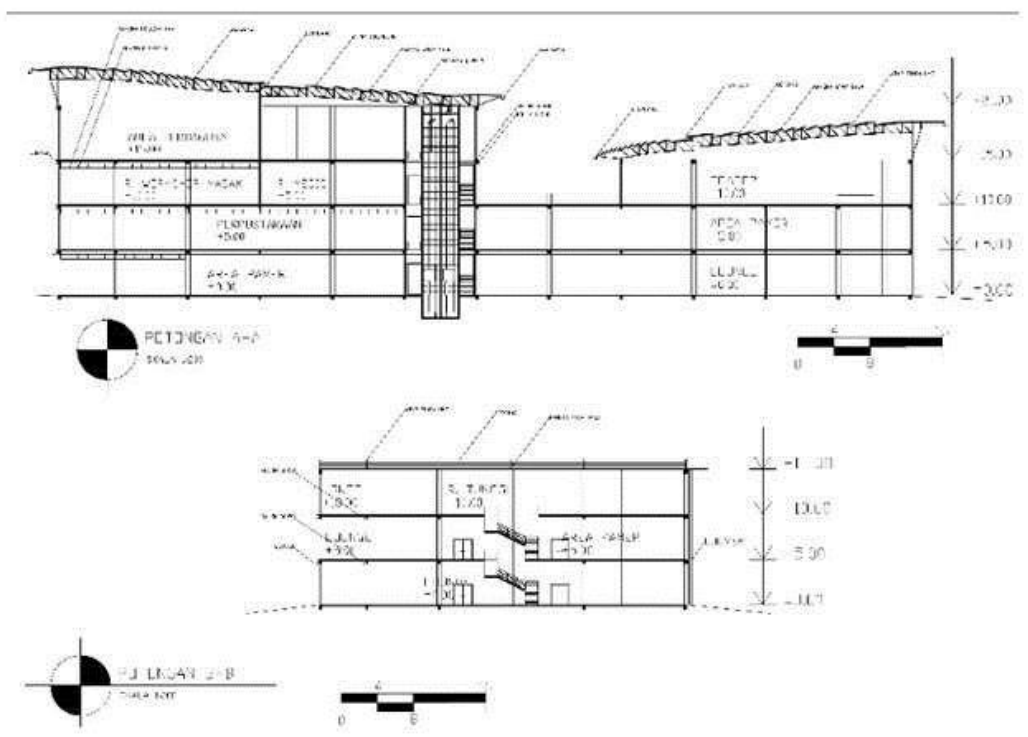

Gambar 22. Potongan A-A dan B-B Bangunan

Sumber: Dokumen Pribadi, 2021

Bagian rangka atap bangunan menggunakan material baja dan atap bangunan sendiri menggunakan material zincalume. Sementara itu pada plafon bangunan digunakan material gipsum.

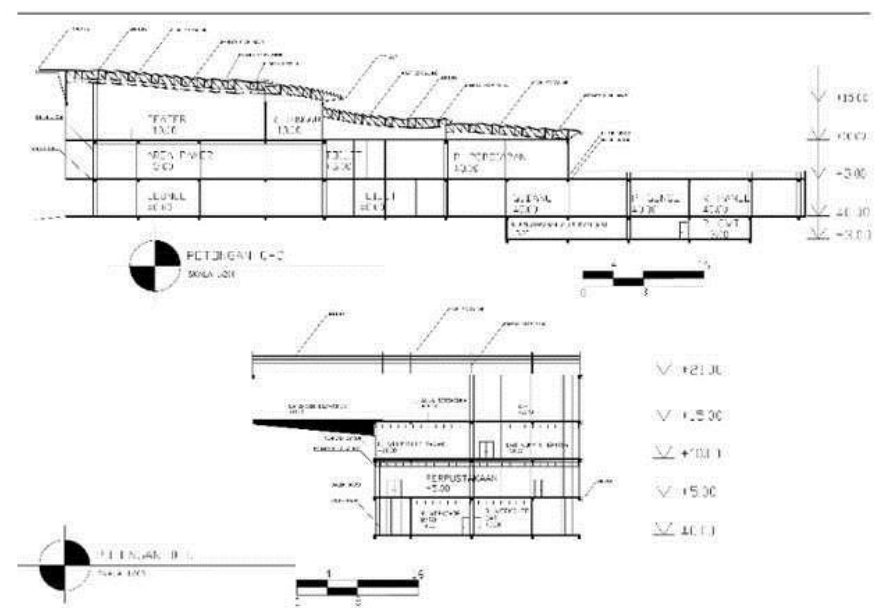

Gambar 23. Potongan C-C dan D-D Bangunan

Sumber: Dokumen Pribadi, 2021 
Pada bagian tampak bangunan juga dapat terlihat jendela yang berbentuk gelombang yang menyesuaikan dengan tema ombak serta adanya elemen kayu sebagai kusen dan ornamen untuk mempercantik fasad bangunan.

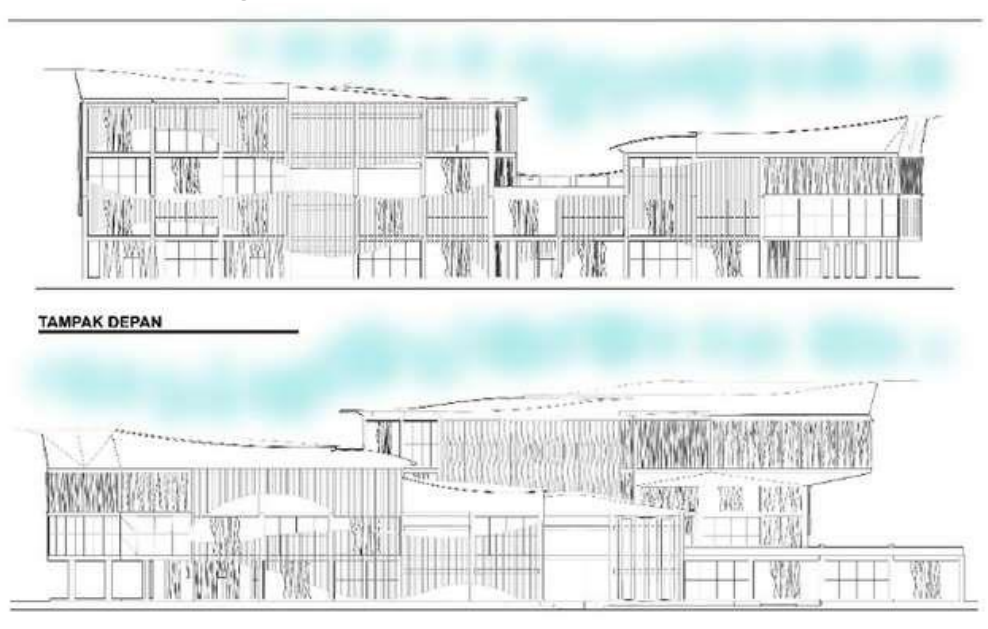

TAMPAK BELAKANG

Gambar 24. Tampak Depan dan Belakang Bangunan Sumber: Dokumen Pribadi, 2021

Sementara itu pada beberapa bagian bangunan hanya menggunakan jendela kaca polos yang dapat dibuka tutup sehingga udara alami dapat masuk kedalam bangunan. Jendela ini juga dimanfaatkan untuk pencahayaan alami ke dalam bangunan.

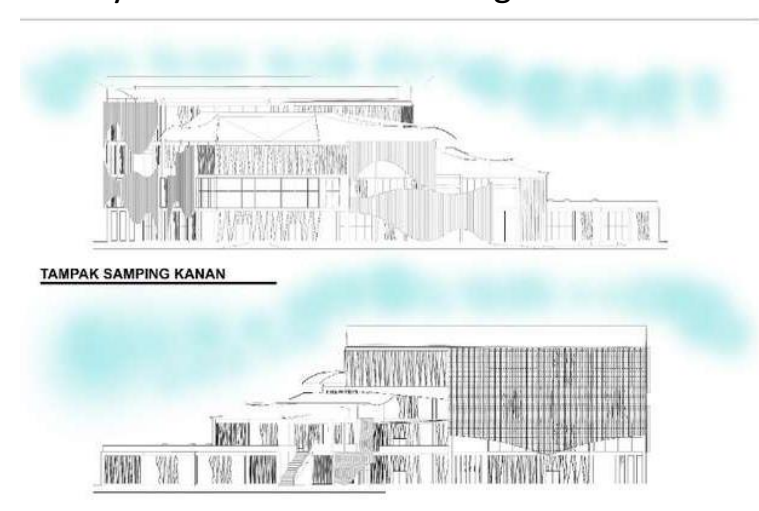

TAMPAK SAMPING KIR

Gambar 25. Tampak Samping Bangunan Sumber: Dokumen Pribadi, 2021

Untuk utilitas bangunan, sirkulasi vertikal pada bangunan menggunakan tangga dan lift. Serta disediakan juga lift barang untuk mengangkut barang pameran dan juga mengangkut alat evakuasi maupun peralatan untuk pengungsi. Pendingin ruang menggunakan $A C V R V$ dan juga AC Split sesuai dengan zona yang sudah dibagi. 


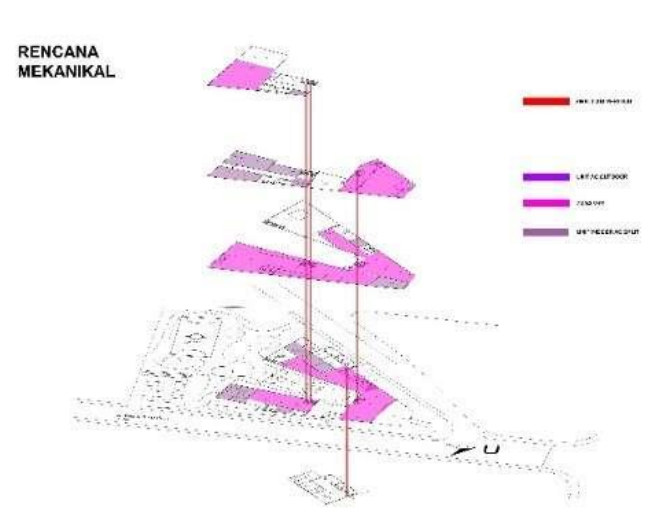

Gambar 26. Rencana Mekanikal Sumber: Dokumen Pribadi

Untuk penyaluran air bersih sendiri, pada bangunan ini menggunakan sistem Rain Water Harvesting. Dimana air hujan dikumpulkan dalam water storage dan disaring kemudian dapat digunakan kembali sebagai sumber air bersih untuk toilet dan sebagainya. Sementara itu air kotor terbagi menjadi 2 yaitu yang disaring kemudian digunakan kembali dan yang langsung disalurkan menuju septic tank dan kemudian disalurkan ke riol kota.

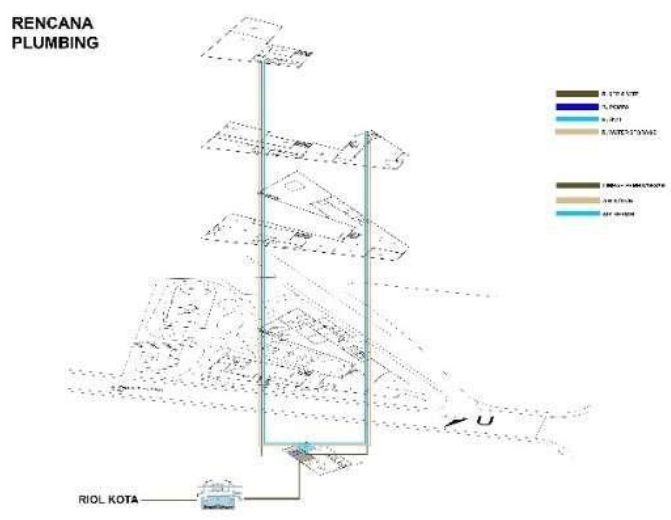

Gambar 27. Rencana Plumbing

Sumber: Dokumen Pribadi, 2021

Sementara itu, untuk rencana elektrikal bangunan menggunakan panel listrik yang ada di lantai dasar. Ada juga ruang genset disamping ruang panel yang digunakan ketika mati listrik terutama ketika terjadinya bencana. Ada juga ruang CCTV untuk keamanan bangunan. 


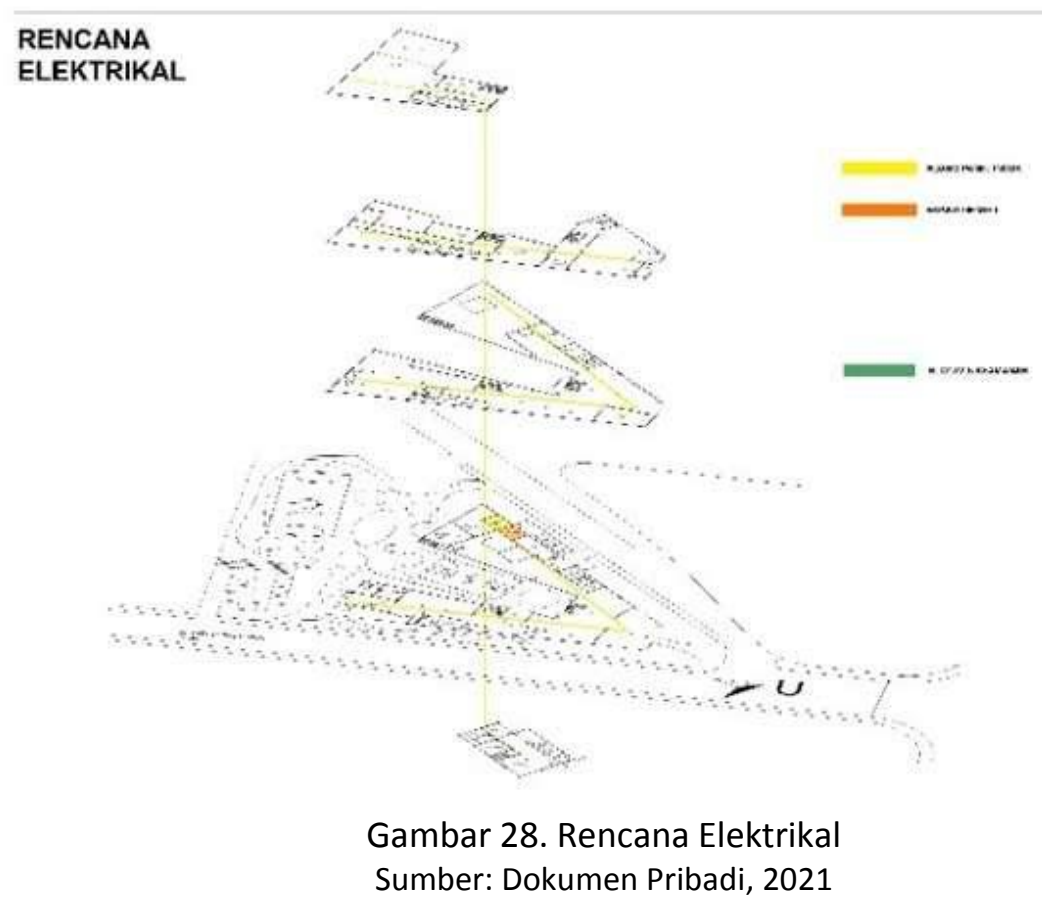

Pada second skin bangunan menggunakan louver yang terbuat dari material aluminium. Sementara itu pada jendela juga menggunakan kusen dan ornamen bermaterial kayu. Balok dan kolom terbuat dari material beton yang di cat sedemikian rupa sehingga terlihat seperti warna kayu dan juga rangka atap menggunakan material baja dengan atap yang bermaterial zincalume.

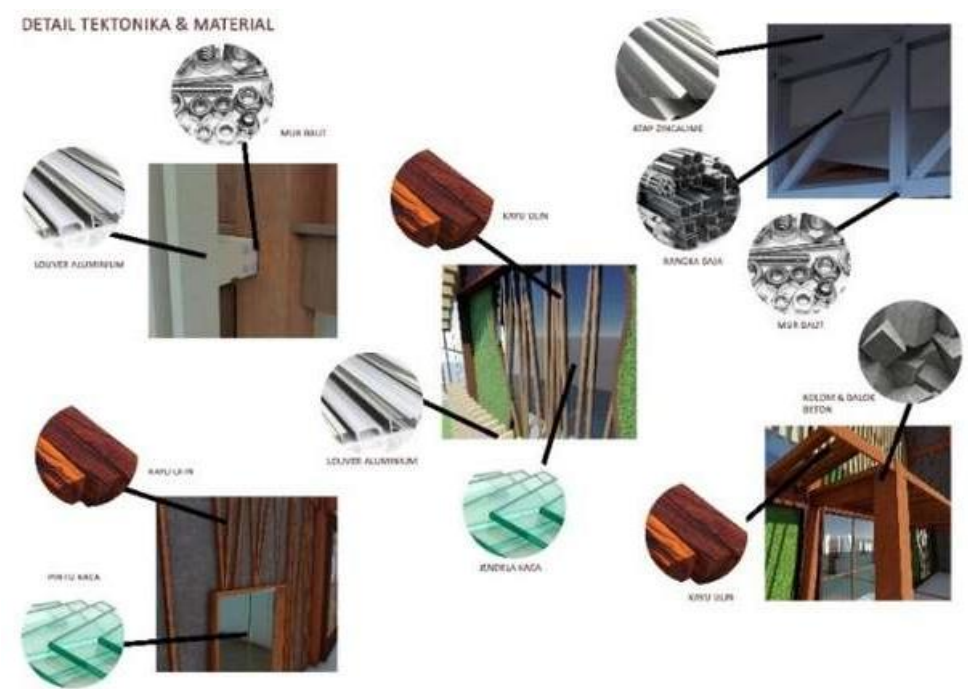

Gambar 29. Detail Tektonika \& Material Sumber: Dokumen Pribadi, 2021

Berikut adalah gambar perspektif eksterior bangunan baik dari sisi jalan Dewi Sartika maupun sisi belakang bangunan serta bagian dalam tapak bangunan. 


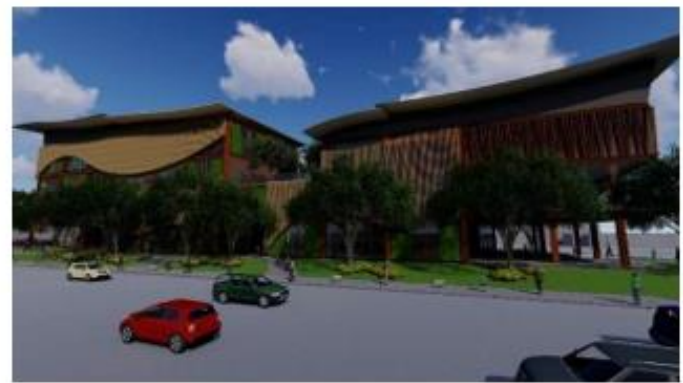

Gambar 30. Perspektif Depan Bangunan Sumber: Dokumen Pribadi, 2021

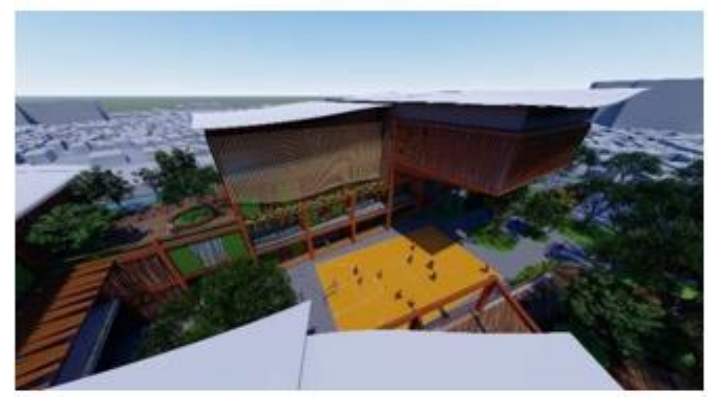

Gambar 32. Perspektif Dalam Tapak Sumber: Dokumen Pribadi, 2021

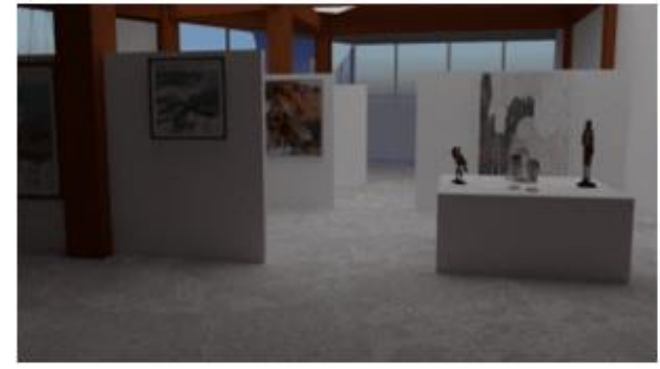

Gambar 34. Area Pamer Lantai 2 Sumber : Dokumen Pribadi, 2021

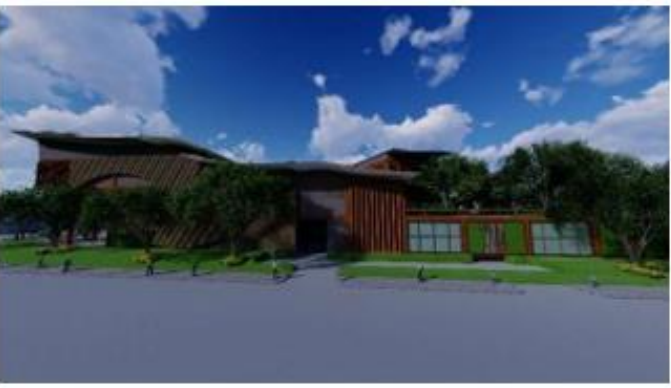

Gambar 31. Perspektif Belakang Bangunan Sumber: Dokumen Pribadi, 2021

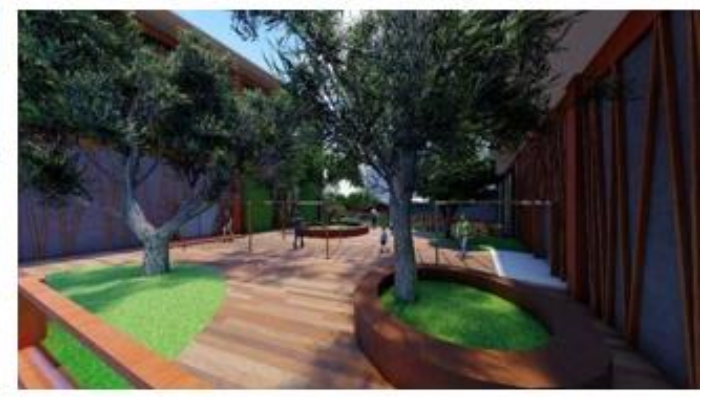

Gambar 33. Taman Lantai 3 Sumber: Dokumen Pribadi, 2021

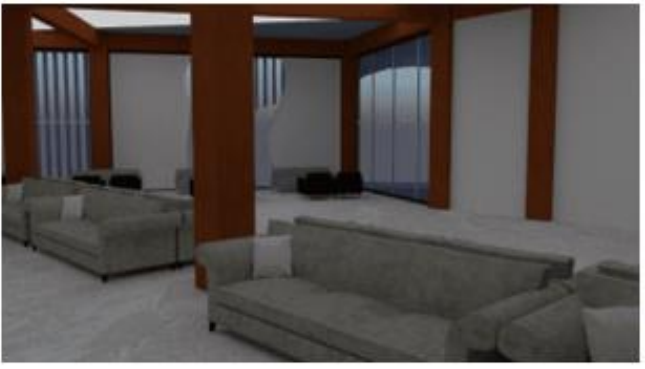

Gambar 35. Lounge Sumber: Dokumen Pribadi, 2021

Berikut adalah beberapa gambar interior banguan seperti area pamer, lounge, lab bahasa dan komputer, serta teater yang beralih fungsi menjadi tempat pengungsian.

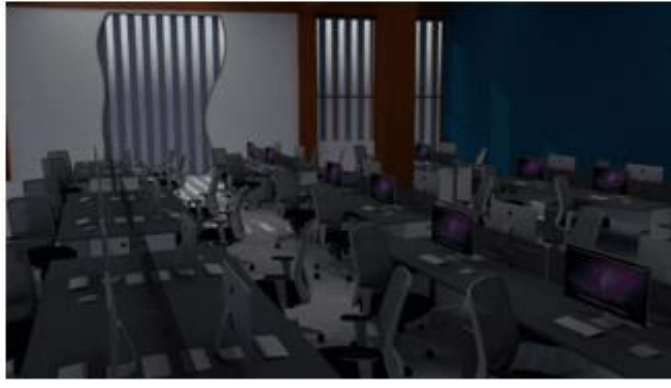

Gambar 36. Ruang Lab Bahasa \& Komputer Sumber: Dokumen Pribadi, 2021

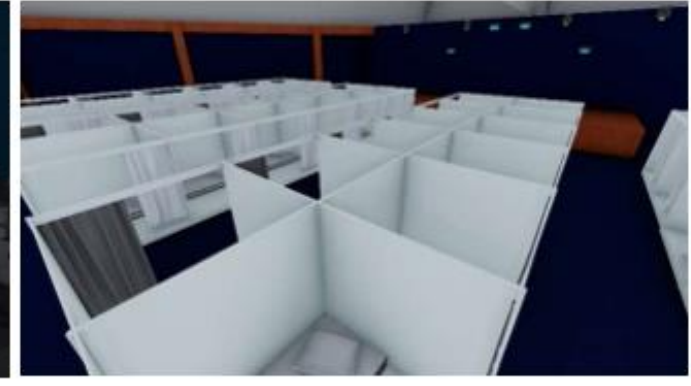

Gambar 37. Teater Ketika Situasi Bencana Sumber: Dokumen Pribadi, 2021 


\section{KESIMPULAN DAN SARAN}

\section{Kesimpulan}

Program ruang sudah memenuhi kebutuhan pengguna baik di situasi normal maupun juga di situasi bencana. Kapasitas tempat pengungsian juga sudah memenuhi standar perkiraan kebutuhan pengguna dimana di satu tempat pengungsian biasanya ditempati oleh 300-500 pengungsi. Untuk sistem dan area pengungsian sendiri sudah cukup efektif. Selain dibekalkan dari bangunan, bantuan seperti dapur umum serta toilet portable juga disediakan di dalam tapak ketika situasi bencana. Desain juga sudah cukup efektif baik dari segi sirkulasi maupun kapasitas dan fasilitas yang disediakan bagi warga baik dalam situasi normal maupun bencana. Untuk mengurangi dampak dari banjir sendiri, desain bangunan ini menggunakan sistem rain water harvesting dimana sebagian air hujan yang turun ditampung untuk digunakan kembali sehingga air tidak hanya terbuang sia-sia ke daratan melainkan dimanfaatkan untuk kebutuhan air bersih warga baik di situasi bencana maupun situasi normal.

\section{Saran}

Hasil rancangan ini masih banyak kekurangan. Diharapkan desain fasilitas ini dapat bermanfaat dan dikembangkan dengan lebih memperhatikan kebutuhan warga agar tetap dapat menjalankan aktivitas sehari-hari seperti bekerja dan belajar.

\section{REFERENSI}

Achmad, H., A. O. (2017). Manajemen Bencana. Kementrian Kesehatan Republik Indonesia.

CNN Indonesia. (2021, February 20). CNN Indonesia. Retrieved from Anies Tetap Targetkan

Banjir Jakarta Surut dalam 6 Jam:

https://www.cnnindonesia.com/nasional/20210220125433-20-608729/anies-tetaptargetkan-banjir-jakarta-surut-dalam-6-jam

Faisol, A. (2021, February 8). Pikiran Rakyat. Retrieved from 13 RT Bidara Cina Jakarta Timur Terendam Banjir, Warga Dievakuasi ke Dua Lokasi: https://www.pikiranrakyat.com/nasional/pr-011401843/13-rt-bidara-cina-jakarta-timur-terendam-banjirwarga-dievakuasi-ke-dua-lokasi

Guattari, F. (2000). The Three Ecologies. London and New Brunswick, NJ: THE ATHLONE PRESS. Haeckel, E. (1866). Oecologie und Chorologie. Volume II, Chapter 11, 286-289.

Hikam, H. A. (2020, February 28). detikFinance. Retrieved from Tinggal di Bantaran Ciliwung, Warga Kebon Pala Tolak Normalisasi!: https://finance.detik.com/infrastruktur/d4918857/tinggal-di-bantaran-ciliwung-warga-kebon-pala-tolak-normalisasi

Kementrian Pekerjaan Umum dan Perumahan Rakyat. (2017). Modul Penanggulangan Bencana Banjir. Bandung: Pusat Pendidikan dan Pelatihan Sumber Daya Air dan Konstruksi.

Nasution, A. M. (2020). Kajian Pola Perilaku Penduduk di Kawasan Permukiman Bantaran Sungai Deli. Journal of Architecture and Urbanism Research, 190-200.

Scuderi, G. (2019, January 11). Designing Flexibility and Adaptability. The Answer to Integrated Residential Building Retrofit, pp. 4-5.

Sutanto, A. (2021). Dromos Oikos. Lecture for STUPA 8, Tarumanagara University.

Van Der Ryn, S. (1996). Ecological Design. Washington D.C: Island Press.

Winata, S. (2021). Ecologic. Lecture for STUPA 8, Tarumanagara University. 